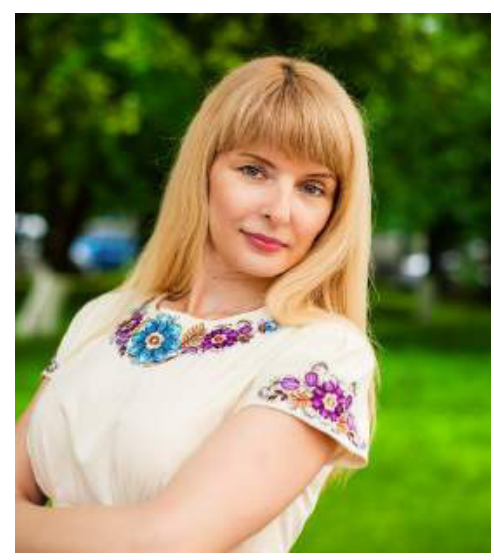

\author{
Оксана Дівнич, \\ аспірант, \\ ДВНЗ «Прикарпатський національний \\ університет імені Василя Стефаника» \\ (м. Івано-Франківськ) \\ Oksana Divnych, \\ Postgraduate Student, \\ Vasyl Stefanyk Precarpathian National University \\ (Ivano-Frankivsk) \\ o_divnuch@ukr.net
}

УдК: 377:005.934.5:316.77(23.0)

ББК: 74.5

\title{
ВПЛИВ ГІРСЬКОГО СЕРЕДОВИЩА НА РОЗВИТОК КОМУНІКАТИВНИХ УМІНЬ МАЙБУТНІХ ФАХІВЦІВ СФЕРИ ОБСЛУГОВУВАННЯ
}

\section{INFLUENCE OF THE MOUNTAIN ENVIRONMENT ON THE DEVELOPMENT OF COMMUNICATIVE SKILLS OF FUTURE SERVICE INDUSTRY SPECIALISTS}

В статті розглядається суть, структура та шляхи формування комунікативних вмінь працівника сфери обслуговування. Наголошується на значенні комунікативних вмінь в успішній професійній діяльності, аналізується вплив гірського середовища на характер комунікативної взаємодії в сфері послуг.

Автор підкреслює, що гірське середовище має специфічний вплив на формування комунікативних вмінь: з одного боку ускладнює процеси комунікативної взаємодії, з іншого - створює сприятливі передумови для динамічного розвитку сфери обслуговування, а значить і формує суспільний запит щодо засвоєння особливих комунікативних вмінь.

Уточнено, що гірське середовище формує особливу локальну ідентичність, на основі якої розвиваються специфічні комунікативні вміння. Завданням освітньої діяльності $\epsilon$ утвердження комунікативних вмінь, в яких би органічно поєднувалися автентичні етнокультурні особливості та глобалізаційні характеристики.

Ключові слова: комунікативні вміння, локальна ідентичність, сфера обслуговування, гірське середовище.

The article deals with the essence, structure and ways of forming the communicative skills of a service worker. It emphasizes the importance of communication skills in successful professional activities, analyzes the influence of the mountain environment on the nature of communicative interaction in the service sector.

The article deals with the essence, structure and ways of forming the service worker communicative skills. The purpose of the article is to analyze the influence of the mountain environment on the development of communicative skills of future professionals in the service sector in order to create conditions for successful professional activity and positive life paths. Common scientific and special methods are used: comparison, analysis and synthesis, system approach, abstraction. It emphasizes the importance of communication skills in successful professional activities, analyzes the influence of the mountain environment on the nature of communicative interaction in the service sector. Communicative skills are an integral part of professional skills and contribute to productive activities, are formed and developed in it, and also make possible the implementation of subjective interaction. Professional activity as a type of social interaction involves the use of appropriate professional speech etiquette. Professional language proficiency of the service sector specialist involves the use of general and professional speech skills. The mountain environment has a specific impact on the formation of communicative skills: on the one hand it complicates the processes of communicative interaction, on the other - it creates favorable conditions for the dynamic development of the service sector, and therefore forms a public request for the mastering of special communicative skills.

It creates a special territorial identity - the perception of the individual as a representative of a certain «imagined community» based on the unity of the residence territory, history and traditions, socio-cultural experience, value orientations and lifestyle. Communicative skills that embody a local identity based on a mountain environment can be the basis for the professional success of service sector providers. The mountain environment forms a special local identity, on the basis of which specific communicative skills develop. The task of educational activity is the establishment of communicative skills, in which the authentic ethnocultural features and globalization characteristics are organically combined.

Keywords: communicative skills, local identity, field of service, mountain environment.

В статье рассматривается суть, структура и пути формирования коммуникативных умений работника сферы обслуживания. Отмечается значение коммуникативных умений в успешной профессиональной деятельности, анализируется влияние горной среды на характер коммуникативного взаимодействия в сфере услуг.

Автор подчеркивает, что горный среда имеет специфическое влияние на формирование коммуникативных умений: с одной стороны усложняет процессы коммуникативного взаимодействия, с другой - создает благоприятные 
предпосылки для динамичного развития сферы обслуживания, а значит и формирует общественный запрос относительно усвоения особых коммуникативных умений.

Уточнено, что горная среда формирует особую локальную идентичность, на основе которой развиваются специфические коммуникативные умения. Задачей образовательной деятельности является утверждение коммуникативных умений, в которых бы органично сочетались аутентичные этнокультурные особенности и глобализационные характеристики.

Ключевые слова: коммуникативные умения, локальная идентичность, сфера обслуживания, горная среда.

Постановка проблеми в загальному вигляді та її зв'язок з важливими науковими та практичними завданнями. Комунікативні вміння $€$ основою успішної професійної діяльності. Комунікативна діяльність фахівця сфери обслуговування полягає у вмінні задовільнити потреби споживача шляхом надання певних послуг і товарів. В той же час, важливо переконати у винятковості свого продукту, що дуже важливо в умовах зростаючої конкуренції на ринку. Тому для ефективної професійної діяльності важливе значення має використання етнокультурних та територіально-просторових особливостей. Відображення особливостей гірського середовище може створити сприятливі умови досягнення успіху у сфері надання послуг.

Аналіз останніх досліджень і публікацій, у яких започатковано розв'язання проблеми. Проблема розвитку комунікативних вмінь у сфері професійного спілкування є предметом наукових зацікавлень багатьох вчених. Вагомий внесок у розробку методики формування комунікативних умінь, розвиток різних видів мовленнєвої діяльності зробили лінгвісти й психолінгвісти Ф. Бацевич, Л. Виготський, В. Григор'єва, І. Зимня, О. Кубрякова, О. Леонтьєв, І. Синиця, С. Фоломкіна, С. Рубінштейн, О. Шахнарович, Л. Щерба та ін. На сьогоднішній день в методиці навчання української мови у вищій школі спостерігаємо неабиякий інтерес до розвитку комунікативних умінь фахівців різних галузей, про що свідчать спеціальні дослідження Н. Безгодової, Г. Берегової, Л. Головатої, Т. Ганніченко, І. Довженко, Л. Златів, М. Ісаєнка, Н. Костриці, В. Михайлюк, Т. Окуневич, О. Попової, Л. Стасів, Н. Тоцької та ін. Проте, недостатня увага приділяється дослідженню методики формування комунікативних вмінь фахівців сфери обслуговування на основі етнокультурних та просторово-географічних характеристик. Гірське середовище має унікальний потенціал щодо розвитку сфери послуг і формування конкурентних преваг на основі використання етнографічного колориту.

Формування мети статті. Метою дослідження $€$ аналіз впливу гірського середовища на розвиток комунікативних умінь майбутніх фахівців сфери обслуговування з метою успішної професійної діяльності та позитивних життєвих траєкторій.

Виклад основного матеріалу дослідження з повним обґрунтуванням отриманих наукових результатів. Для успішного спілкування фахівець сфери обслуговування повинен володіти необхідними комунікативними вміннями. Узагальнюючи комунікативні вміння працівника сфери обслуговування, можна виділити найбільш важливі: уміння організовувати процес спілкування і керувати ним (створення моделі процесу майбутнього спілкування, встановлення емоційного контакту, об'єктивна оцінка партнера по спілкуванню, здійснення рефлексії під час спілкування, прогнозування результату комунікації); уміння активізувати спілкування (застосування вербальних і невербальних засобів спілкування, їх вміле поєднання); уміння організовувати обмін інформацією (дотримання етичних норм при використанні різних технік спілкування) [1, с.43].

Комунікативні вміння є складовою професійних вмінь і сприяють продуктивній діяльності, формуються і розвиваються в ній, а також роблять можливим здійснення суб'єктивної взаємодії. Професійна діяльність як вид соціальної взаємодії передбачає використання відповідного професійного мовленнєвого етикету.

Професійний мовленнєвий етикет - це система словесних формул спілкування, стійких висловів, які використовуються у ситуаціях професійної взаємодії. Володіння професійним мовленнєвим етикетом фахівця сфери обслуговування передбачає використання загальних та професійних мовленнєвих умінь. При цьому загальні мовленнєві уміння - це володіння вербальними засобами, дотримання професійно спрямованих мовленнєвих норм, уміння використовувати обрані мовленнєві засоби у процесі вирішення індивідуальних й колективних виробничих ситуацій, формування персоніфікованого стилю власного мовлення, уникання мовних штампів, послідовне, чітке формулювання висловлювань, володіння мовленнєвим етикетом.

Застосування загальних мовленнєвих умінь доповнюються професійними мовленнєвими уміння, що передбачають володіння професійною лексикою, термінологією, різними формами писемного та усного професійного мовлення; уміння створювати тексти, що використовуються у ситуаціях професійної комунікації; використання термінології сфери обслуговування, спеціальної фразеології, стійких висловів, які відповідають соціально значимим ситуаціям професійної комунікації; здійснювати аналіз ефективності професійної комунікації; удосконалення власного професійного мовлення; добір найдоцільніших у професійному спілкуванні мовленнєвих моделей.

Використання професійного мовленнєвого етикету фахівця сфери обслуговування дозволяє планомірно будувати різні етапи комунікативних процесів, урізноманітнювати й увиразнювати власне мовлення; здійснювати взаємодію на основі знань про закономірності спілкування й способи управління індивідом та групою; доцільно використовувати у своїй діяльності професійну лексику; складати документи різного призначення.

Створення дидактичних умов формування професійного мовленнєвого етикету майбутніх фахівців сфери обслуговування передбачає їх мотивацію до вивчення мовленнєвого етикету, формування позитивного ставлення 
до діяльності, розвиток пізнавальної активності, усвідомлення особистісного смислу навчання професійному мовленнєвому етикету, використання індивідуального підходу, поєднання групових та індивідуальних форм роботи.

Важливу роль в процесі ефективного формування навичок професійного мовленнєвого етикету фахівця сфери обслуговування відіграють наявність позитивної мотивації діяльності; зацікавленість особистості питаннями мови і мовної культури; систематизація набутих знань; використання різноманітних вправ, що моделюють ситуації спілкування на різних рівнях: «зверху-вниз». «знизу-верх» та «по-горизонталі», моделювання ситуацій, наближених до реальних, за допомогою добору мовного матеріалу, що використовується в мовленні фахівців відповідного профілю, системи тренінгів, комунікативних вправ, завдань, рольових ігор, навчального діалогу.

Гірське середовище має специфічний вплив на формування комунікативних вмінь: з одного боку ускладнює процеси комунікативної взаємодії, з іншого - створює сприятливі передумови для динамічного розвитку сфери обслуговування, а значить і формує суспільний запит щодо засвоєння особливих комунікативних вмінь.

Гори залишаються середовищем особливого спілкування людини з дикою природою [2, с.92]. Особливі природні умови, нестабільний суворий клімат, розмірений часовий ритм, віддаленість більшості сіл від адміністративних, наукових та культурних центрів, недостатньо розвинута інфраструктура впливають на формування та розвиток сфери обслуговування.

Проте гірське середовище із неповторною мальовничою природою та автентичною культурою приваблює населення, що актуалізує потребу в комунікативній взаємодії щодо надання послуг та реалізації товарі.

Гірське середовище формує особливу територіальну ідентичність - це сприйняття індивідом себе як представника певної «уявленої спільноти», яка ґрунтується на єдності території проживання, історії та традицій, соціокультурного досвіду, ціннісних орієнтацій та способу життя [3, с. 114]. Територіально-просторова ідентичність, як правило, представлена наступними рівнями: локальним (місцевим); регіональним; державним/національним; глобальним. Локальна ідентичність уособлює собою первинний (базовий, основний) рівень територіальнопросторової ідентичності. Термін «локальний» $є$ похідним від латинського «localis», що означає «конкретне місце» або «розташування у просторі». Локальна ідентичність може реалізовуватися через ідентифікацію з окремими елементами, зокрема: з місцем народження/малою батьківщиною; з особливостями місцевого ландшафту і клімату; із відомими місцевими історико-культурним подіями; із значимими людьми: з близькими та рідними, друзями (безпосередні контакти); колегами по роботі; відомими особами; з економічною спеціалізацією місця і рівнем його соціально-економічного розвитку; з особливими реальними або приписуваними межами колективної поведінки [4, с.140]. Локальна ідентичність - це результат ототожнення людиною себе 3 певним місцем фізичного простору, що має символічну і ціннісну значущість, специфічну культуру. Вона формується під впливом колективного та індивідуального досвіду і взаємодії в межах локальної спільноти.

Комунікативні вміння, які втілюють локальну ідентичність на основі гірського середовища, можуть стати основою професійного успіху працівник сфери обслуговування. Мовленнєві конструкції, що реалізуються в процесі професійної комунікації повинні поєднувати етнографічну специфіку з тенденціями загально цивілізаційного розвитку.

Висновки і перспективи подальших досліджень. Комунікативні вміння є основою успішної професійної діяльності. Комунікативна діяльність фахівця сфери обслуговування полягає у вмінні задовільнити потреби споживача шляхом надання певних послуг і товарів. Комунікативні вміння є складовою професійних вмінь і сприяють продуктивній діяльності, формуються і розвиваються в ній, а також роблять можливим здійснення суб'єктивної взаємодії. Гірське середовище формує особливу локальну ідентичність, на основі якої розвиваються специфічні комунікативні вміння. Завданням освітньої діяльності є утвердження комунікативних вмінь, в яких би органічно поєднувалися автентичні етнокультурні особливості та глобалізаційні характеристики.

1. Волкова Н. П. Професійно-педагогічна комунікація: теорія, технологія, практика : [монографія] / Н.П. Волкова. - Донецьк : Вид-во ДНУ, 2005. - 304 с.

2. Ковальчук В. Особливості організації навчально-виховної роботи в гірських школах// Гірська школа Українських Карпат. 2007. - № 2-3. - С. 92-97.

3. Коржов Г. Територіальні ідентичності: концептуальні інтерпретації в сучасній зарубіжній соціологічній думці // Соціологія: теорія, методи, маркетинг. - 2010. - №1. - С.107-124.

4. Локальная идентичность: формы актуализации и типы / Е. В. Морозова, Е. В. Улько. - ПОЛИТЭКС. - 2008. - № 4. C. $139-151$.

\section{Reference}

1. Volkova N. P. Profesiino-pedahohichna komunikatsiia: teoriia, tekhnolohiia, praktyka : [monohrafiia] / N.P. Volkova. - Donetsk : Vyd-vo DNU, 2005. - 304 s.

2. Kovalchuk V. Osoblyvosti orhanizatsii navchalno-vykhovnoi roboty v hirskykh shkolakh// Hirska shkola Ukrainskykh Karpat. - 2007. № 2-3. - S. 92-97.

3. Korzhov H. Terytorialni identychnosti: kontseptualni interpretatsii v suchasnii zarubizhnii sotsiolohichnii dumtsi // Sotsiolohiia: teoriia, metody, marketynh. - 2010. - №1. - S.107-124.

4. Lokal'naja identichnost': formy aktualizacii i tipy / E. V. Morozova, E. V. Ul'ko. - POLITEKS. - 2008. - № 4. - S. 139 -151.

Рецензент: Луцан Н.І., доктор педагогічних наук, професор, ДВНЗ «Прикарпатський національний університет імені Василя Стефаника» 